\title{
A Family Problem: The Effects of Parental Alcohol on Children
}

\author{
Hatice Şen-Aslan ${ }^{1}$
}

Şen-Aslan, H. (2021). A family problem: The effects of parental alcohol on children. Nesne, 9(19), 127-138. DOI: $10.7816 /$ nesne-09-19-10

Keywords
children of
alcoholics,
alcoholic parents,
alcohol problem,
children's well-
being

Anahtar

kelimeler alkolik ebeveynlerin çocukları, alkolik ebeveynler, alkol problemi, çocukların iyilik hali

\begin{abstract}
Alcohol misuse does not just adversely affect individual who uses alcohol, but also family system where the individual live in. Because of dysfunctionalities of people with alcohol problem such as lack of responsibility and disruption in roles, family home environment may become more chaotic and unstable. In these conditions, non-alcoholic family members may develop problems as well. In the present review, it is aimed to examine how the alcoholic parents influence their children in means of psychosocial and behavioral outcomes. Family is the most important factor for children socialization process and positive family environment is necessary for children's well-being. Children learn and develop some basic skills such as sense of self, coping strategies and how to regulate their emotions in family environment thanks to their parents. By examining the effects on children of alcoholic parents (CoAs) and by being aware of risk and protective factors, those children's wellbeing can be protected. To know damages parental alcohol abuse on the family and how resiliency might be enhanced, the importance of a family centered preventions and treatments to protect family peace is increased.
\end{abstract}

\section{Bir Aile Sorunu: Ebeveyn Alkol Kullanımının Çocuklar Üzerindeki Etkileri}

Öz

Alkol kötüye kullanımı sadece alkol kullanan bireyi değil, o kişinin içinde yaşadığı aile sistemini olumsuz şekilde etkiler.Alkol problemi olan kişilerin rollerini ve sorumluluklarını yerine getirememesi gibi işlevsizliklerden dolayı, ailenin yaşadığı ev ortamı daha karmaşı ve düzensiz hale gelir. Bu koşullar altında, ailenin diğer üyelerinde de problemler görülebilir. Mevcut literatür derlemesinde, alkolik ebeveynin çocuklarını psikososyal ve davranışsal açıdan nasıl etkilediğini incelemek amaçlanmıştır. Aile çocukların sosyalizasyonu için en önemli faktördür ve pozitif bir aile ortamı çocuğun iyilik hali için gereklidir. Çocuklar kendilik algısı, baş etme stratejileri ve duygularını nasıl düzenleyeceği gibi temel becerileri ailede kazanır. Alkolik ebeveynin çocuklar üzerindeki etkileri incelenerek ve çocukları daha savunmasız hale getiren ve olumsuz etkilerden koruyan faktörlerin de farkında olarak, bu çocukların iyilik hali korunabilir. Ebeveynin alkol bağımlılığının aile üzerindeki yıkımlarını ve dayanıklılı̆̆ın nasıl artacağını bilmek, aile huzurunu korumak için aile merkezli müdahale ve tedavilerin önemini arttırır.
Article History

Arrived: March 4, 2020

Revised: December 19, 2020

Accepted: February 7, 2021
Autor Note: I would like to thank Asst. Prof. Yağmur Ar Karc1 for her support.

DOI: $10.7816 /$ nesne-09-19-10

${ }^{1}$ MSc, TED University, Developmental Focused Clinical Child and Adolescent Psychology, hatice.sen(at)tedu.edu.tr. ORCID: 0000-0001-5363-1365 
Alcohol use disorder is related to frequent and intense drinking and alcoholic people develop tolerance to the amount of alcohol intake, so they drink more to satisfy with the alcohol effect. They have no control over their drinking and they are heavy drinkers. They show withdrawal effects such as anger, dizziness and shaking when they want to drink and do not have access to alcohol. They cannot think of anything else even though they harm people around (American Psychiatric Association, 2013). Alcoholics have several problems. Alcohol use disorder leads alcoholic people to the dysfunction in their lives. Their daily routines are disrupted and they cannot even go to work and so they can be unemployed. Their cognitive functioning is also negatively influenced, and their decision making, memory skill, attention and reasoning abilities are restricted. They have impulsive behaviors and so they are open to accidents. They may have alcohol-related disorders such as cardiovascular diseases, cancer, and liver cirrhosis. Mortality resulting from alcohol use disorder is about $5 \%$ of the all deaths which is 3 million people. Alcohol problem is a severe risk for people and $40 \%$ of drinkers show heavy episodic drinking (World Health Organization, 2019). People with an alcohol problem mostly develop psychological disorders as well, and antisocial behaviors and depression are among the most seen disorders (Eiden, Colder, Edwards \& Leonard, 2009). They have aggressive behaviors and have a higher tendency to apply violence. Therefore besides the harms of alcohol on themselves, alcoholic people also harm others and society in general. Criminal behaviors are often seen and they may damage property, so they are more possible to have problems with the justice system (World Health Organization, 2019).

If alcoholic people are parents, alcohol effects are damaging for the whole family. There is a disorganized home environment because alcoholic parents do not fulfill their roles and responsibilities and do their routines. Other family members take much more roles and responsibilities. They most probably live in low socioeconomic conditions. When alcoholic parents are compared with nonalcoholic parents, alcoholics are less educated than others (Erdim, 2019; Park \& Schepp, 2015). Family conflict is often seen at the home where alcoholic people live (Hung, Yen \& Wu, 2009). Because of higher numbers of alcoholic fathers than alcoholic mothers, violence and aggression are more likely to be encountered in a home environment where alcoholic fathers live. Verbal, physical and emotional abuse is high in these homes and so family members have traumatic experiences (Erdim, 2019; Park \& Schepp, 2015). Communication between family members has also affected adversely and it is more aggressive based because of alcoholic parents' aggression and abuse (Haverfield, Theiss \& Leustek, 2016). There may not be positive interaction among family members and so family cohesion is poor. In general, alcohol-related subjects are not talked inside and outside of family and they feel ashamed of the situation. Therefore alcohol is hidden subject and family members make socially isolated themselves (Finan, Schulz, Gordon \& Ohannessian, 2015). Alcoholic parents' parenting is the opposite of those what a child's need. They do not approach as warm and sensitive to their children (Eiden et al., 2009). They do not support them and show interest in children's needs (Pisinger, Bloomfield \& Tolstrup, 2016). Neglect and rejection are mostly seen by alcoholic parents to their children. CoAs get inconsistent messages and whatever they do is not validated by their parents. Thus, negative parenting of alcoholic parents leads children to feel inadequate (Mahato, Ali, Jahan,Verma \& Singh, 2009; Park \& Schepp, 2015). Alcoholic parents can have a harmful effect on their partners' parenting as well, and non-alcoholic partners may show inconsistent parenting including overcontrol and neglect. Nonalcoholic partners of alcoholics exhibit less warmth and support while they are playing with their children (Eiden et al., 2009; Guttmannova et al., 2017). The reason for that could be a negative home setting and they have excessive responsibilities for the whole family. Additionally, nonalcoholic partners may develop psychosocial problems. This can bring negative environment more unpredictable and chaotic, because both 
alcoholic parent and non-alcoholic partner have problems and so they do not fulfill their roles. Family members besides alcoholic parent may develop emotional, social and behavioral problems because of the negative experiences they have (Erdim, 2019; Park \& Schepp, 2015). Therefore, as we see these home conditions which alcoholic parents cause, alcohol misuse is actually a family problem. Alcoholic people are not the only ones who are being harmed, but also their families as the closest ones are harmed a lot (Erdim, 2019).

In the present literature review, the effect of alcoholic parents on their children will be examined. Family is important for children's social-emotional development, for example, children's identity development, adaptive behaviors, social skills, sense of self and others and regulation of behaviors and emotions start to develop at home. If children have parents with an alcohol problem, the children's general well-being is affected negatively (Singh, 2017). By examining the effects of alcoholic parents on children and what risk and protective factors are, we can know which kind of effective interventions and preventions we should apply in a clinical setting.

\section{Children Outcomes}

Both having alcoholic parents and living in the adverse home conditions which are resulted from alcoholics are disturbing impacts on children's general well-being. Beginning from early ages to adulthood, children's negative well-being persists by increasing its severity. While behavioral symptoms are mostly seen in early childhood, with increasing age children develop more serious problems such as criminal behaviors and suicide (Erdim, 2019; Park \& Schepp, 2015). When it is looked at components of well-being, most common impacts on well-being are psychosocial and psychopathological impacts.

\section{Psychosocial Impacts}

Alcohol problems of parents develop from the beginning from their adolescence and so their children face with their parents' alcoholism from the beginning of their life (Guttmannova et al., 2017). Infants of alcoholic parents have difficult temperament including reactivity and neuroticism in higher level than children of non-alcoholics. These children are more fearful to outside stimulus because they do not feel in safe in their family environment and they think outside is also dangerous (Hussong, Flora, Curran, Chassin \& Zucker, 2008; Kendler et al., 2013). CoAs have an insecure-avoidant attachment because their parents are not there for children's emotional needs and these parents show rejection and neglect. In the future, CoAs show insecure, fearful relationships with their romantic partners and they also have an avoidant attachment with their partners as well (Park \& Schepp, 2015). Additionally, CoAs' peer relationships are not adaptive. They may also be avoidant and insecure in their friendships. If CoAs are aggressive and they have problem behaviors, they more likely have delinquent friends. As it is understood, these children do not have supportive and positive role models so they may not develop social skills. When they meet a problem, their coping mechanisms are poor. They have difficulty to understand own emotions and regulate them in an adaptive way (Erdim, 2019; Park \& Schepp, 2015). CoAs have low self-efficacy and so they feel inadequate whatever they do. These children have intense stress in life and they lose their belief in themselves (Singh, 2017). When children of alcoholics and non-alcoholics from infancy to preschool ages are evaluated, children at 2-3 ages show lower self-regulation than non -alcoholics' children because for both the direct effect of parental alcoholism and unsupportive and less warmth parenting. Accordingly, they show negative self-esteem (Omkarappa \& Rentala, 2019). When children started kindergarten, CoAs show less social competence than other kids because of both direct effect of alcoholism and lack of self-regulation. They are 
less cooperative, less autonomous and less happy in the (Eiden et al., 2009). They may become behind their peers in the fields of motoric skills, problem-solving and social skills (Guttmannova et al., 2017). Therefore they show adjustment problems at school. These children also have less academic success. When children completed their compulsory years at school, more likely CoAs do not continue to high school compared with other children of non-alcoholics (Berg, Bäck, Vinnerljung \& Hjern, 2016).

Children of alcoholics are like growing themselves alone without safe, support and warmth feelings from caregivers. They have much more responsibility and they may have to work because of low economic conditions at home. They may show parentification which is about children's taking adult roles to support their parents by putting aside their own emotional and physical needs, and they care in house works, earning money and they look after their siblings and alcoholic parents. Since alcoholic parents are dysfunctional and they do not fulfill their roles and responsibilities, and children take those roles and responsibilities (Kelley et al., 2007). Children of alcoholics show some common patterns in means of roles in the family and they are enabler, hero, lost, scapegoat and mascot. Enabler children make alcoholic parents' life easy because they take responsibilities and do everything right for not making alcoholic parent angry. Those children most probably show parentification. Hero children are mature and responsible. They are hard workers and help the family to be seen as functional from outside. Lost children do not show themselves around and escape from family conflict. They may stay their homes all day and so they stay invisible. They do not face with their emotions and more avoidant to themselves and others. Scapegoat children take attention from alcoholic parents to themselves and distract the family's main problem which is alcoholic parents. They show externalizing problems and get trouble. They fail at school. Mascot children use humor to decrease the effect of family conflict at home. They seem not to care anything, but deep inside they have excessive fear (Vernig, 2011). As explained, those children have different strategies to deal with problems of alcoholic parents. They do not show positive development as much as their peers without alcoholic parents. In a deeper level, they all have fear to outside.

\section{Psychopathological Impacts}

Negative experiences children of alcoholics have such as home violence, parental aggression, and family conflict lead the children to have mental health problems and they may develop psychopathology. Researches show that the most seen psychopathologies in CoAs are externalizing disorders, internalizing disorders, and alcohol and substance abuse. When children of alcoholic parents and children of nonalcoholic parents are compared in the studies, it shows that CoAs more likely to have antisocial and aggressive behaviors. They more prone to break rules, and so they show oppositional behaviors to others (Finan et al., 2015). They may have conduct problems and show criminal behaviors. As it is seen they have the possibility of following similar paths with their parents. Attention Deficit and Hyperactivity Disorder (ADHD) can be seen commonly as well (Eiden et al., 2009; Kendler et al., 2013; Park \& Schepp, 2015). About externalizing disorders in general while alcoholic mothers' influences do not differ on their sons' and daughters' symptoms, alcoholic fathers have much more effect on their sons' symptoms (Long, Lönn, Sundquist, Sundquist \& Kendler, 2018). When gender factor was examined on children behavior problems, sons of alcoholic parents more develop externalizing disorders than daughters of alcoholics. These results can be explained with gender roles because externalizing behaviors are more acceptable for males than females. On the contrary, daughters of alcoholics report much more internalizing symptoms than sons (Pissinger et al., 2016; Serec et al., 2012). For girls, it is expected them to less talk and be emotional, and in the family of alcoholic parents, the girls have more responsibility to care the home and emotional needs of the family (Kelley et al., 2007). 
Moreover, alcoholic parents' children develop higher internalizing disorders such as depression and anxiety than children of non-alcoholics. These behaviors are consistent and severe from early childhood to adolescence. If alcoholic parents also have depression and antisocial behaviors, internalizing symptoms are more severe (Hussong et al., 2008; Omkarappa \& Rentala, 2019). A study about emotional symptoms of adolescents of alcoholic parents states that adolescent children of both alcoholic biological and step parents show higher depression, loneliness and emotional symptoms such as irritability and being nervous than nonalcoholic biological and step-parents (Pissinger et al., 2016). In the review of Park and Schepp (2015), adolescents whose parents have problem drinking are under the risk of eating problem as well. The adolescent children of alcoholics who have higher internalizing symptoms also report that their feelings are not important for their parents and their parents do not trust them. Children of alcoholics seem their emotional needs are not met (Pissinger et al., 2016). A longitudinal study about children's both externalizing and internalizing behaviors found that by controlling alcoholic parents' psychopathology, financial problems and education level alcoholic parents lead children more likely to have somatoform disorders, learning disorders and language problems as well as depression, anxiety, ADHD and conduct problems. It is seen that even though parents' psychopathology and economic difficulties are controlled, still alcoholic parents have a highly damaging effect on children's problems. Since traumatic experiences are higher in this group and it affects deep inside of individuals negatively. It is important to know that alcohol problems of parents have disturbing effects on children no matter which severity of alcohol abuse (Raitasalo Holmila, Jääskeläinen \& Santalahti, 2018).

Alcoholic parents' children more likely show early onset of alcohol, substance, cigarette and sexual relationship compared to non-alcoholic parents' children. Early onset of alcohol and substance has higher trajectory from the early adolescence to young adulthood and those children more likely develop alcohol and substance abuse (Alati et al., 2014; McCutcheon et al., 2018; Serec et al., 2012). CoAs' higher amount of alcohol use is related to genetic transmission from their parents according to twin and adoption studies (Campbell \& Oei, 2010). Children's alcohol problem can also be explained with social cognitive learning theory. Since, children learn behaviors by observing what their parents do and imitating them (Bandura, 1986). If parents are positive role models, children develop positive and adaptive behaviors. However, alcoholic parents exhibit heavy drinking, aggressive and problem behaviors and their children are raised by exposing these behaviors. Because of these adverse conditions including family conflict and low parental support, children are prone to drink and nonadaptive behaviors similar to their parents (Hung et al., 2009). As an additional explanation for children's alcohol use in early ages and developing alcohol use disorder, cognitions of alcoholic parents about alcohol use have the possibility to be transferred to their children because of modeling their alcoholic parents. They have information about alcohol at earlier ages than children in same age groups. The children of alcoholics may have more positive expectations regarding alcohol and these expectations can be about forgetting their problems being more social when they are drunk (Campbell \& Oei, 2010). As seen, these children begin their life with an alcohol problem and its negative consequences. The problems which children develop are like a legacy from their alcoholic parents. If both parents are alcoholics, it increases the possibility of developing alcohol and substance problems on children and early onset may decrease to 12 ages. As alcoholic parents' gender effect is examined, while alcoholic mothers much more lead their daughters to develop substance problems, alcoholic fathers lead their sons to have substance problems (McCutcheon et al., 2018). Since, children may have role models of their parents; while boys may take roles models of their fathers and internalize their behaviors, girls may see role models as their mothers and internalize their behaviors much more. 
As it is known, suicide is a serious risk when there is a psychopathology. Children of alcoholics have higher suicide ideas and attempts than non-alcoholic parents' children. In addition, those children show much more self-harm behaviors and it is twice as much than non-alcoholic groups. These suicidal behaviors are much more studied beginning from early adolescence. It is consistent with the idea that with increasing ages, children's severity and extent of symptoms increase. These adolescents report that they feel insecure and are being yelled and scolded at their homes (Pisinger, Hawton \& Tolstrup, 2018). Their negative experiences including antisocial behaviors of parents, family conflict and violence at home and negative parenting make them feel unsafe and fearful and so they find life is unbearable.

\section{How was the adaptation process for CoAs?}

Many of the studies related to parental alcohol focus on psychosocial and pathological outcomes on children of alcoholic parents. However, we do not know in detail how the children perceive their experiences and how their adaptation process is. In a qualitative study done with alcoholic fathers' adult children, they are asked retrospectively to share their experiences about how living with alcoholic parents was alike, how their current life is affected and what they expect from future. Adult children of alcoholics show common themes in their experiences and perceptions. They report that they were not aware of what is going on around. They feel helpless and fearful. They start to be aware that it is not normal. Their peers' fathers go to work, spend time with them, treat well to their children, but adult children of alcoholics do not experience these things. With increasing age, CoAs struggle to stop drinking with their alcoholic parents. They might talk and try to convince them to get treatment. When alcoholic fathers get help and then they start to drink again, children feel a big frustration. When they understand that their parents do not change, they minimize communication with their alcoholic parent. They keep both physical and emotional distance between themselves and their parents. Their parents never would be in their lives anyway. They report they do not follow the same path with their alcoholic parents. They want to become supportive and responsible parents themselves. Their alcoholic parents are an anti-role model for them. However, it does not mean that they will be opposite of their alcoholic parents, and maybe they become parents just like their parents. They may internalize those negative behaviors of the parents even they do not want to be like them. In their current life, adult children show different separation strategies to keep distance between themselves and what they experienced. Some of the adult children state these experiences are traumatic and they do not want to remember. They use comforting techniques by engaging their hobbies and daily routines. They start a new different life. They may be a hard worker and to create different conditions for themselves. If they develop understanding, they feel pity and worry for their parents. They accept that the parents have a psychological problem and so their behaviors are not on purpose and they lose control. Adult children of alcoholics showing understanding to their parents do empathy with their parents and they understand their parents' stressful life (Park \& Schepp, 2017). Moreover, adult children who think their parents have mental disorder more likely to seek help for their parents compared to adult children who think their alcoholic parents are guilty. Those who see parents as bad think their parents chose alcohol instead of their family and they show more blame and anger toward to alcoholics (Järvinen, 2015). As it is seen, there are both children of alcoholics separating themselves adaptively from the negative experiences they live and children internalizing the experiences. Moreover, for both psychopathological and psychosocial outcomes are not seen all CoAs. Therefore it is important to understand which factors make children more vulnerable to develop psychopathological and psychosocial problems (risk factors) and which factors prevent them to have these problems (protective factors). 


\section{Risk and Protective Factors}

If there are additional risk factors in addition to parental alcohol, children problem outcomes increase more. For instance, if there are two alcoholic parents in a family, it makes children more vulnerable to show externalizing and internalizing symptoms (Mahato et al., 2009). Since none of the caregivers would be there for their needs and family home environment is more chaotic. Both parents would act impulsively and aggressively and so they have more conflict. The children quite likely show early onset of alcohol and substance problems (Hung et al., 2009). As it is mentioned before, the alcohol problem has comorbidity with other disorders which are mostly depression, antisocial behaviors, and substance abuse. If children have alcoholic parents with additional psychopathologies, it makes children have more negative experiences and so their problems increase (Hussong et al., 2008). Since those parents show much more dysfunctionalities and they cannot show positive parenting. CoAs cannot feel being loved, supported and safe, because their alcoholic parents engage in their own problems. Non-alcoholic partners of alcoholics are important for taking care of children and for family functioning, but they may develop psychopathology in the family because of emotional distress of alcoholics. It affects children more adversely because they lose their other parent's care as well. If family cohesion is weak and children do not have close relationships with other family members, it leads them to feel alone in the chaotic house. Family conflict, neglect, and violence increase experiencing trauma and it is known that trauma has a damaging effect on self and is more possible to be experienced in a home where alcoholic parents live (Pisinger et al., 2016). Socioeconomic conditions are also important for children outcomes. In low socioeconomic conditions, there are higher losts for children and they also need to struggle with financial problems besides social and emotional problems. Children in low socioeconomic status cannot reach healthy foods as well. They more likely engage in sedentary activities such as watching TV rather than physical activities. Therefore they also have physical problems and are hospitalized more often. They do not even meet basic human needs (Park \& Schepp, 2015; Serec et al., 2012). As can be seen, the factors making children more vulnerable to problem outcomes are all related to negative experiences which alcoholic parents consist.

Even though there is an alcoholic parent at home and but other family members might function well in appropriate conditions and if children have a positive self, it may prevent children from more negative experiences and protect them from psychopathological and negative psychosocial outcomes. Higher self-regulation of children prevents them to have alcohol problems (Pearson, D'Lima \& Kelley, 2011). They could control themselves and do not follow the same way with their alcoholic parents. They show higher social competence compared to children of alcoholics with low self-regulation (Eiden et al., 2009). High self-esteem is also an important factor for children not to develop psychopathology and it helps children to believe themselves and their capabilities. Moreover, children may be hard workers to find an escape way from their livings; by becoming successful they find a good job and start a new family distant from their alcoholic parents. If non-alcoholic partners show positive parenting with support, appropriate discipline, warmth, and sensitiveness, children of alcoholics less likely to develop problems. Children can meet attachment need with these parents. Non-alcoholic parents would be buffer for these children (Park \& Schepp, 2015). Family cohesion and positive interaction in the family are factors helping children to deal with problems of alcoholic parents and not develop externalizing behaviors, and children feel being supported, listened and cared (Finan et al., 2015). Living in moderate to high socioeconomic conditions makes children reach easier both healthy foods and extracurricular activities to help their well-being. As related to socioeconomic conditions, well-educated parents with alcohol problems also help children's well- 
being and the children show less internalizing behaviors (Hussong et al., 2008). In a study related to adult children of alcoholics, $26 \%$ of adult children's narratives include positive themes about the effect of their parents. These adult children report they become more mature, feel proud of not being alcoholic as their parents and become good parents contrary to their parents. They show adaptive separation from their parents. When they asked what helped them to deal with negative experiences, they say that they have social support, there was lower family conflict and they have positive coping skills toward problems (Amodeo, Griffin \& Paris, 2011). Here it is clear that while children of alcoholics are more open to problem outcomes when there are additional risk factors, they may overcome negative experiences adaptively when they have protecting factors. It is important to understand what children of alcoholics experience and which outcomes they show, and what makes vulnerable them to develop problems and what protects their well-being. By being aware of those, the necessary steps for preventions and interventions can be taken.

\section{Conclusion and Clinical Implications}

As a family problem, parents with alcohol abuse have disturbing effects on their families. Children are the most vulnerable to the effects of alcoholic parents. Since they need a secure attachment figure when they are growing up and a positive role model to learn what kind of people they will become. Their social and emotional development starts in their family environment and they use tools which they learn through life. However, children of alcoholic parents do not experience a positive family environment and so their total well-being is affected negatively. Parents' alcohol problem is a threat to family peace. Regardless of the maternal or paternal alcohol problem and also the severity of alcohol problem, parental alcohol is associated with children's psychopathological and psychosocial outcomes (Pisinger et al., 2016; Raitasalo et al., 2018). Mental health difficulties of CoAs do not differ whether children currently live with their alcoholic parents or not and they have the adversities regardless of living poorer economic conditions (Pisinger et al., 2016; Serec et al., 2012). The psychopathological outcomes and psychosocial outcomes may persist from early ages to adulthood by increasing severity. Therefore it is important to be aware of the risk and protective factors to help those children not to develop psychopathology and psychosocial problems.

In these COVID-19 pandemic times, psychological distress has increased on individuals and families because of social and economic restrictions, closure of schools, increasing of uncertainty in life and threat of infection. Economic conditions got worse and some people lost their jobs. People in those conditions might feel depressed, anger and anxious. Therefore, relationships among family member might be influenced negatively (Prime, Wade \& Browne, 2020). All those stressors increased with pandemic have risks on family violence (Humphreys, Myint \& Zeanah, 2020). Reports showed that alcohol consumption and relapses have increased in pandemic. The reason might be increasing of stressors, people's dysfunctional coping styles and perceiving alcohol as a solution of problems (Sun et al., 2020). Alcohol is a threat to family at home during quarantine, because children and non-alcoholic parents are often and severely exposed to alcoholic parent. Lockdown restricted social life and so those family members might feel much more lonely and helpless. It makes family members much more vulnerable to emotional and psychological problems. As mentioned before, higher alcohol consumption increases child neglect and abuse and also family violence (Erdim, 2019). To protect children from harms of parental alcohol in the lockdown during pandemic, individuals in society including health workers, teachers, relatives and neighbors should observe children's emotional, behavioral and academic changes and physical complaints. Noticing and reporting child abuse and family violence help starting treatment and increasing mental health of alcoholic and nonalcoholic family members. 
As family system perspective supported, family consists of different members and interactions among family members and functioning of one member affect the whole family. As it was reported, parents who misuse alcohol affect all other family members' well-being. Besides alcoholic parents' treatment with an alcohol problem, family members also should be in the treatment process and get help (Saatcioglu, Erim \& Cakmak, 2006). Because of that alcohol problem of parents is actually a whole family's problem, family therapy would become the first choice for treatment. It would be helpful because their family is dysfunctional, relationships and interactions among family members are poor, roles and responsibilities are not fulfilled adaptively well. Even though alcoholic parents do not want to participate in the therapy, the rest of the family can take benefits. Since, family therapy aims to help the family to reorganize themselves to function well. Because of the chaotic and unpredictable environment, the family members could not develop effective coping strategies. Treatment also provides family members to obtain positive coping mechanisms. The therapy benefits the parents to take their roles and responsibilities, and so children can have a more predictable home and they will not need to take a big responsibility as if they are parents (Burnett, Jones, Bliwise \& Ross, 2006). The treatment should also include parental training for non-alcoholic parents and alcoholic parents if they accept to participate and take alcohol treatment. Parent training can include positive communication with children, positive discipline strategies and being supportive and warm to their children (Eiden et al., 2009). These might motivate alcoholics to get benefit from alcohol treatment. Enhancing communication in these families is important because they have aggressive and avoidant communication with each other (Haverfield et al., 2016). Additionally, individuals who have alcohol problem and their families could be encouraged to take social support from their trusted and loved friends and relatives. Social support might be strength for the family member in the treatment process.

For the younger children, help them to understand what is going on and why their alcoholic parents treat them negatively will be beneficial. It can be explained that their parents are sick and need help and so it makes easier for children to understand their alcoholic parents and they can overcome adaptively (Järvinen, 2015). Alcohol problem stays as a secret at home and children may not open their emotions to their own family or outside. Children need to be listened nonjudgmentally. For older children, group therapies can be helpful to share their experiences and notice that there are others experiencing similar things with them. Children who face with alcoholic parents and adverse situations in early ages are more vulnerable to develop problems because their physical and psychological needs are not answered. However, older children can protect their mental health from the effects of the traumatic home environment. Children who have those negative experiences from the beginning of early ages come to treatment when they are grown up and they come with bigger problems (Park \& Schepp, 2015; Raitasalo et al., 2018). For these reasons, early intervention is significant. Interventions should aim to increase protective factors in children's lives including parent-child relationships, increasing self-esteem and self-regulation. Moreover, children who live in low economic conditions and have poor school performance may be followed in their schools carefully, because alcohol problems are strongly associated with low economic conditions and poor school performance (Berg et al., 2016; Serec et al., 2012). By determining the children of alcoholics by cooperating with schools and teachers, CoAs can be reached and they can get treatment. When alcoholic parents are hospitalized, their family members should be taken to treatment and treatment should be affordable for those in low socioeconomic status. After alcohol treatment, alcoholic parents and their families should be followed and it can be home visits to evaluate family's well-being. The chaotic home environment needs to be reorganized and skills for children use should be enhanced. As conclusion, comprehensive interventions including individual misusing alcohol, family, social supports of family, children's school, health services and justice systems would be more effective for prevention and intervention of the adverse impacts of 
parental alcohol on children (Syed, Gilbert \& Wolpert, 2018). By increasing protective factors and retransforming adverse family environment towards to more positive one and by decreasing risk factors such as negative parenting, negative communication and family conflict, children's psychopathology, and related problems can be intervened and they can become resilient against the negative effects of parental alcohol.

\section{References}

Alati, R., Baker, P., Betts, K. S., Connor, J. P., Little, K., Sanson, A., \& Olsson, C. A. (2014). The role of parental alcohol use, parental discipline and antisocial behaviour on adolescent drinking trajectories. Drug and Alcohol Dependence, 134, 178-184.

Amodeo, M., Griffin, M., \& Paris, R. (2011). Women's Reports of Negative, Neutral, and Positive Effects of Growing up with Alcoholic Parents. Families in Society, 92(1), 69-76.

American Psychiatric Association. (2013). Diagnostic and statistical manual of mental disorders (DSM-5). American Psychiatric Pub.

Bandura, A. (1986). Social foundations of thought and action. Englewood Cliffs, NJ, 23-28.

Berg, L., Bäck, K., Vinnerljung, B., \& Hjern, A. (2016). Parental alcohol-related disorders and school performance in 16-year-olds - a Swedish national cohort study. Addiction, 111(10), 1795-1803.

Burnett, G., Jones, R. A., Bliwise, N. G., \& Ross, L. T. (2006). Family unpredictability, parental alcoholism, and the development of parentification. The American Journal of Family Therapy, 34(3), 181-189.

Campbell, J. M., \& Oei, T. P. (2010). A cognitive model for the intergenerational transference of alcohol use behavior. Addictive Behaviors, 35(2), 73-83.

Eiden, R. D., Colder, C., Edwards, E. P., \& Leonard, K. E. (2009). A longitudinal study of social competence among children of alcoholic and nonalcoholic parents: Role of parental psychopathology, parental warmth, and self-regulation. Psychology of Addictive Behaviors, 23(1), 36-46.

Erdim, L. (2019). Alkolizmin aile ve çocuk üzerine etkisi. Sağllk Bilimleri ve Meslekleri Dergisi, 6(1), 193200.

Finan, L. J., Schulz, J., Gordon, M. S., \& Ohannessian, C. M. (2015). Parental problem drinking and adolescent externalizing behaviors: The mediating role of family functioning. Journal of Adolescence, 43, 100-110.

Guttmannova, K., Hill, K. G., Bailey, J. A., Hartigan, L. A., Small, C. M., \& Hawkins, J. D. (2017). Parental alcohol use, parenting, and child on-time development. Infant and Child Development, 26(5), e2013.

Haverfield, M. C., Theiss, J. A., \& Leustek, J. (2016). Characteristics of communication in families of alcoholics. Journal of Family Communication, 16(2), 111-127.

Humphreys, K. L., Myint, M. T., \& Zeanah, C. H. (2020). Increased risk for family violence during the COVID-19 pandemic. Pediatrics, 146(1).

Hung, C. C., Yen, L. L., \& Wu, W. C. (2009). Association of parents' alcohol use and family interaction with the initiation of alcohol use by sixth graders: a preliminary study in Taiwan. BMC Public Health, $9(1)$.

Hussong, A. M., Flora, D. B., Curran, P. J., Chassin, L. A., \& Zucker, R. A. (2008). Defining risk heterogeneity for internalizing symptoms among children of alcoholic parents. Development and Psychopathology, 20(1), 165-193.

Järvinen, M. (2015). Understanding addiction: Adult children of alcoholics describing their parents' drinking problems. Journal of Family Issues, 36(6), 805-825. 
Kelley, M. L., French, A., Bountress, K., Keefe, H. A., Schroeder, V., Steer, K., ... \& Gumienny, L. (2007). Parentification and family responsibility in the family of origin of adult children of alcoholics. Addictive Behaviors, 32(4), 675-685.

Kendler, K. S., Gardner, C. O., Edwards, A., Hickman, M., Heron, J., Macleod, J., ... \& Dick, D. M. (2013). Dimensions of parental alcohol use/problems and offspring temperament, externalizing behaviors, and alcohol use/problems. Alcoholism: Clinical and Experimental Research, 37(12), 2118-2127.

Long, E. C., Lönn, S. L., Sundquist, J., Sundquist, K., \& Kendler, K. S. (2018). The role of parent and offspring sex on risk for externalizing psychopathology in offspring with parental alcohol use disorder: a national Swedish study. Social Psychiatry and Psychiatric Epidemiology, 53(12), 13811389.

Mahato, B., Ali, A., Jahan, M., Verma, A. N., \& Singh, A. R. (2009). Parent-child relationship in children of alcoholic and non-alcoholic parents. Industrial Psychiatry Journal, 18(1), 32-35.

McCutcheon, V. V., Agrawal, A., Kuo, S. I. C., Su, J., Dick, D. M., Meyers, J. L., ... \& Schuckit, M. A. (2018). Associations of parental alcohol use disorders and parental separation with offspring initiation of alcohol, cigarette and cannabis use and sexual debut in high-risk families. Addiction, 113(2), 336-345.

Omkarappa, D. B., \& Rentala, S. (2019). Anxiety, depression, self-esteem among children of alcoholic and nonalcoholic parents. Journal of Family Medicine and Primary Care, 8(2), 604-609.

Park, S., \& Schepp, K. G. (2015). A systematic review of research on children of alcoholics: Their inherent resilience and vulnerability. Journal of Child and Family Studies, 24(5), 1222-1231.

Park, S., \& Schepp, K. G. (2017). The Patterns of Adaptation While Growing Up Under Parental Alcoholism: A Grounded Theory. Journal of Child and Family Studies, 26(7), 1875-1887.

Pearson, M. R., D'Lima, G. M., \& Kelley, M. L. (2011). Self-regulation as a buffer of the relationship between parental alcohol misuse and alcohol-related outcomes in first-year college students. Addictive Behaviors, 36(12), 1309-1312.

Pisinger, V. S., Bloomfield, K., \& Tolstrup, J. S. (2016). Perceived parental alcohol problems, internalizing problems and impaired parent—child relationships among 71988 young people in Denmark. Addiction, 111(11), 1966-1974.

Pisinger, V. S., Hawton, K., \& Tolstrup, J. S. (2018). Self-injury and suicide behavior among young people with perceived parental alcohol problems in Denmark: a school-based survey. European Child \& Adolescent Psychiatry, 27(2), 201-208.

Prime, H., Wade, M., \& Browne, D. T. (2020). Risk and resilience in family well-being during the COVID19 pandemic. American Psychologist.

Raitasalo, K., Holmila, M., Jääskeläinen, M., \& Santalahti, P. (2018). The effect of the severity of parental alcohol abuse on mental and behavioural disorders in children. European Child \& Adolescent Psychiatry, 1-10.

Saatcioglu, O., Erim, R., \& Cakmak, D. (2006). Role of family in alcohol and substance abuse. Psychiatry and Clinical Neurosciences, 60(2), 125-132.

Serec, M., Švab, I., Kolšek, M., Švab, V., Moesgen, D., \& Klein, M. (2012). Health-related lifestyle, physical and mental health in children of alcoholic parents. Drug and Alcohol Review, 31(7), 861870.

Singh, A. (2017). Self-efficacy and well-being in adolescent children of alcoholic parents. Indian Journal of Health \& Wellbeing, 8(7), 619-621.

Sun, Y., Li, Y., Bao, Y., Meng, S., Sun, Y., Schumann, G., ... \& Shi, J. (2020). Brief report: increased addictive internet and substance use behavior during the COVID-19 pandemic in China. The American Journal on Addictions, 29(4), 268-270. 
Syed, S., Gilbert, R., \& Wolpert, M. (2018). Parental alcohol misuse and the impact on children: a rapid evidence review of service presentations and interventions. London: Children's Policy Research Unit.

World Health Organization. (2019). Global status report on alcohol and health 2018. World Health Organization.

Vernig, P. M. (2011). Family roles in homes with alcohol-dependent parents: An evidence-based review. Substance Use \& Misuse, 46(4), 535-542. 